\title{
Dasar Pertimbangan Hakim Menetapkan Hak Asuh Anak Kepada Suami Selaku Pemohon pada Pengadilan Agama Jambi
}

\author{
Maryati* \\ Fakultas Hukum Universitas Batanghari, Jambi, Indonesia \\ Jl. Slamet Ryadi, Broni-Jambi \\ *Correspondence email: maryati@unbari.ac.id
}

\begin{abstract}
Abstrak. Suami atau istri merupakan orang tua yang sama-sama berhak dan berkewajiban untuk mengurus anak-anaknya, tetapi karena terjadi suatu perceraian, penguasaan dan pengurusan anak-anak tidak bisa dilakukan secara bersama-sama, sehingga terjadi perselisihan antar kedua orang tua tersebut. Atas dasar hal tersebut, maka anak yang akan menanggung akibat dari perceraian yang dilakukan oleh kedua orangtuanya. Tujuan Penelitian ini adalah: a) Untuk mengetahui dan menganalisis apa yang menjadi dasar pertimbangan hakim dalam menetapkan hak asuh anak diberikan kepada suami selaku pemohon pada Pengadilan Agama Jambi dan b) Untuk mengetahui dan menganalisis akibat hukum terhadap hak asuh anak yang diberikan kepada suami selaku pemohon. Metode penelitian yang digunakan dalam penulisan ini adalah pendekatan yuridis empiris. Kesimpulan penelitian ini adalah bahwa dalam perkara Nomor 122/Pdt.G/2019/PA. Jmb Pertimbangan Majelis Hakim dalam menetapkan hak asuh anak yang belum mencapai usia 12 tahun kepada ayah kandungnya secara psikologis karena demi mewujudkan kemasalahatan dan kepentingan anak itu sendiri, karena jika anak tersebut ditetapkan pada ibu kandungnya, yang didasarkan pada fakta di persidangan ibu kandungnya tidak memiliki kecakapan dan kemampuan untuk memenuhi kepentingan anak secara normal.
\end{abstract}

Kata kunci: pertimbangan haim; hak asuh anak; pengadilan agama

Abstract. Husband or wife are parents who have the same right and obligation to take care of their children, but because of a divorce, the control and management of the children cannot be done together, resulting in a dispute between the two parents. On the basis of this, the child will bear the consequences of the divorce carried out by both parents. The purposes of this study are: a) To find out and analyze what is the basis for the judge's consideration in determining child custody given to the husband as the applicant at the Jambi Religious Court and b) To find out and analyze the legal consequences of child custody given to the husband as the applicant. The research method used in this paper is an empirical juridical approach. The conclusion of this study is that in case Number 122/Pdt.G/2019/PA. The consideration of the Panel of Judges in determining the custody of a child who has not yet reached the age of 12 years to his biological father psychologically is for the sake of realizing the problems and interests of the child himself, because if the child is assigned to his biological mother, which is based on the facts at trial the biological mother does not have the skills and the ability to meet the interests of the child normally.

Keywords: haim consideration; child custody; religious courts

\section{PENDAHULUAN}

Pada prinsipnya tujuan perkawinan adalah membentuk keluarga yang bahagia dan kekal. Hal ini ditegaskan dalam Undang-Undang Nomor 1 Tahun 1974 tentang Perkawinan, yaitu ucapan lahir batin antara seorang pria dengan seorang wanita sebagai suami istri dengan tujuan membentuk keluarga (rumah tangga) yang berbahagia dan kekal berdasarkan ketuhanan Yang Maha Esa. Namun, terkadang fenomena berbicara lain, perkawinan yang diharapkan sakinah, mawadah, warohmah ternyata karena satu dan lain hal harus kandas di tengah jalan yang disebabkan karena salah satu pasangan ada yang berselingkuh sehingga sering terjadi pertengkaran dan perselisihan yang terus menerus antara suami dan istri yang sudah tidak dapat didamaikan lagi.

Perceraian menurut Abdur Rahman Ghazali mengutip definisi dari beberapa tokoh, diantaranya $:^{1}$

${ }^{1}$ Abdul Rahman Ghazali, Fiqih Munakahat, Kencana Prenada Group, Jakarta, 2010. halaman. 191-192.
1. Sayyid Sabiq berpendapat bahwa perceraian adalah melepas tali perkawinan dan mengakhiri hubungan suami istri.

2. Al-Jaziry mendefinisikan talak adalah menghilangkan ikatan perkawinan atau mengurangi pelepasan ikatannya dengan menggunakan kata-kata tertentu.

3. Abu Zakaria Al-Anshari mengartikan talak yakni melepas tali akad nikah dengan kata talak dan yang semacamnya.

Pasal 19 Ayat 2 Undang-Undang Nomor 1 Tahun 1974 tentang Perkawinan yang menjelaskan keadaan yang dapat dijadikan alasan perceraian di antaranya:

a. Salah satu pihak berbuat zina atau menjadi pemabuk, pemadat, penjudi, dan lain sebagainya yang sulit disembuhkan.

b. Salah satu pihak meninggalkan pihak lain selama 2 tahun berturut-turut tanpa izin pihak lain dan tanpa alasan yang sah atau karena hal lain di luar kemampuannya. 
c. Salah satu pihak mendapat hukuman selama 5 tahun atau lebih berat setelah perkawinannya berlangsung

d. Salah satu pihak melakukan kekejaman atau penganiayaan berat yang membahayakan pihak lain.

e. Salah satu pihak mendapat cacat badan atau penyakit dengan akibat tidak dapat menjalankan kewajiban suami istri.

f. Antara suami istri terus menerus terjadi perselisihan dan pertengkaran dan tidak ada harapan untuk rukun lagi dalam rumah tangga.

Pelaksanaan perceraian tidak selalu mendatangkan faedah kebaikan tetapi juga mendatangkan kemudharatan bagi keluarga yang melakukannya. Timbulnya berbagai perselisihan dan konflik di antara suami, istri, ipar, keluarga mertua dan besan serta pada anak-anak yang dilahirkan dari perkawinan ini tidak bisa dihindari.

Dengan terjadinya perceraian, maka timbullah berbagai akibat hukum, bukan hanya terpisah antara suami dengan isteri, melainkan juga pemisahan harta bersama, pengurusan terhadap anak dan lain sebagainya yang dapat mendatangkan permasalahan bagi mereka yang melakukan perceraian itu sendiri.

Salah satu akibat yang timbul dengan terjadinya perceraian tersebut adalah pengurusan terhadap anak, dimana bisa saja anak tidak ada yang mengurusnya atau antara kedua pasangan yang bercerai saling menginginkan mengurus/menguasai anak tersebut. Anak yang dimaksud adalah anak sah perkawinan, dalam Pasal 42 Undang-Undang Nomor 1 Tahun 1974 adalah "anak yang dilahirkan dalam atau sebagai akibat perkawinan yang sah".

Menurut ketentuan peraturan perundangundangan yang berlaku setiap anak mempunyai hak untuk dilindungi, terutama hak untuk mendapatkan kasih sayang dari kedua orang tuanya. Bentuk perlindungan hukum terhadap anak menurut ketentuan Pasal 13 Undang-Undang Nomor 35 Tahun 2014 tentang Perubahan Atas Undang-Undang Nomor 23 Tahun 2002 tentang Perlindungan Anak adalah berupa :

(1) Setiap anak selama dalam pengasuhan orang tua, wali, atau pihak lain manapun yang bertanggung jawab atas pengasuhan, berhak mendapat perlindungan dari perlakuan :
a. diskriminasi;
b. eksploitasi, baik ekonomi maupun seksual;
c. penelantaran;
d. kekejaman, kekerasan dan penganiayaan;
e. ketidak adilan;
f. perlakuan salah lainnya.

(2) Dalam hal orang tua, wali atau pengasuh anak melakukan segala bentuk perlakuan sebagaimana dimaksud dalam ayat (1), maka pelaku dikenakan pemberatan hukuman.
Guna menunjukkan tanggung jawab untuk pengurusan anak, suami dan isteri yang bercerai kadangkala berebut untuk menguasainya, yang akhirnya terjadi perselisihan antara keduanya. Dengan terjadinya perselisihan untuk penguasaan anak berakibat penyelesaiannya harus sampai ke lembaga pengadilan, yaitu Pengadilan Negeri berlaku bagi mereka yang beragama non-muslim atau yang tidak tunduk pada ketentuan hukum Islam, sedangkan Pengadilan Agama berlaku bagi mereka yang tunduk pada hukum Islam atau hukum nasional berupa Undang-undang Nomor 1 Tahun 1974.

Apabila diketahui adanya suatu kendala dalam pemeriksaan maupun penyelesaian perkara perceraian di pengadilan, perlu segera dilakukan upaya penanggulangan agar tidak merambat ke kasus-kasus lain yang sama, yang akhirnya menghilangkan kewibawaan hakim maupun pengadilan.

Terlepas dari hal tersebut di atas, berhasil atau tidaknya suami istri yang mengajukan perceraian dan memperebutkan hak asuh anak, maka akibat hukum akan berlaku terhadap anak, dan ketika terjadi perceraian maka pertanggungjawaban nafkah anak dan sebagainya tetap berada pada suami atau ayah si anak.

Dalam kenyataan, terkadang pihak yang memenangkan perkara perceraian dan memperebutkan hak asuh anak, juga memiliki permasalahan dalam hal kemampuan untuk mencukupi kebutuhan anaknya. Sedangkan salah satu orang tua selaku pihak yang kalah ada yang terkadang hanya memberikan nafkah anak seadanya sebagai bentuk pertanggung jawabannya setelah perceraian. Dengan terjadinya hal ini, disatu sisi hakim terkadang keliru dalam menentukan pihak yang dianggap mampu untuk menjaga dan merawat anaknya dan disisi lain kurangnya rasa tanggung jawab orang tua yang bercerai terhadap anaknya. Sedangkan berdasarkan peraturan perundang-undangan yang berlaku, anak berhak mendapatkan pemenuhan kebutuhan hidupnya dan kasih sayang serta perlindungan dari kedua orang tuanya. Hal ini tersurat dari ketentuan Pasal 41 UndangUndang Nomor 1 Tahun 1974, yang menentukan :

Akibat putusnya perkawinan karena perceraian ialah :

a. Baik ibu atau bapak tetap berkewajiban memelihara dan mendidik anak-anaknya, semata-mata berdasarkan kepentingan anak, bilamana ada perselisihan mengenai penguasaan anak-anak, pengadilan memberi keputusannya;

b. Bapak yang bertanggung jawab atas semua biaya pemeliharaan dan pendidikan yang diperlukan anak itu, bilamana bapak dalam kenyataan tidak memberi kewajiban tersebut. Pengadilan dapat menentukan bahwa ibu ikut memikul biaya tersebut.

c. Pengadilan dapat mewajibkan kepada bekas suami untuk memberikan biaya penghidupan dan atau menentukan suatu kewajiban bagi bekas isteri. 
Dalam penulisan skripsi ini, penulis akan memfokuskan penelitian pada pertimbangan hakim dalam menetapkan hak asuh anak kepada suami atau ayah.

Pelaksanaan hak asuh anak pasca perceraian, menurut Darmo yang mengemukakan bahwa:

\begin{abstract}
"Dalam perjalanan kesadaran manusia, dikenal dua macam hak yaitu pertama, hak yang melekat pada seseorang begitu ia lahir sebagai manusia dan kemanusiaannya. Inilah yang disebut sebagai hak asasi manusia (HAM) sebagai hak dasar kodratinya sebagai manusia dan melekat atas kemanusiaannya untuk berkembang sebagai pribadi berharkat meliputi hak mendapatkan pendidikan dan penghidupan yang layak. Kedua, hak yang bersumber dari tindakan atau laku manusia yang bebas untuk berpendapat, bersuara, berserikat dan membuat pilihan-pilihan perjanjian di bawah kontrak. Dengan berbingkai pemahaman, penalaran dan penghayatan mengenai sesuatu yang disebut adil, maka lahirlah keadilan individual sebagai rasa yang ditentukan oleh seseorang berdasarkan apa yang dia serap dari tradisi kultur masyarakatnya dan ia jadikan pandangan, serta keadilan sosial ketika wujud yang adil itu dikonstuksi oleh struktur kuasa, hubungan kuasa ekonomis, budaya dan sosial kehidupan masyarakatnya. Maka ketika memaknai keadilan, tidak dipandang secara parsial apa yang menurut pandangan pribadinya adalah adil". ${ }^{2}$
\end{abstract}

Pelaksanaan hak asuh anak pasca perceraian tidak dapat dilepaskan dari adanya konsep keadilan individu dan kultur masyarakat yang merupakan salah satu sumber untuk menilai keadilan tersebut.

Dari hasil penelitian yang penulis lakukan pada Pengadilan Agama Jambi, diketahui jumlah data perkara hak asuh anak yang diputus pada Pengadilan Agama Jambi dari Tahun 2016 sampai dengan bulan Mei 2019, yakni pada tahun 2016 terdapat sebanyak 15 perkara yang hak asuh anak diberikan kepada ibunya, pada tahun 2017 terdapat sebanyak 26 perkara yang hak asuh anak diberikan kepada ibunya, pada tahun 2018 terdapat sebanyak 12 perkara yang hak asuh anak diberikan kepada ibunya, dan pada tahun 2019 terdapat 6 perkara yang hak asuh anak diberikan kepada ibunya dan 1 perkara yang hak asuh anak diberikan kepada ayahnya.

Berdasarkan data yang telah penulis uraikan diatas, bahwa jumlah hak asuh anak yang diputus dan ditetapkan oleh hakim pada Pengadilan Agama Jambi paling banyak diberikan pada si istri selaku termohon/penggugat, sedangkan hak asuh anak yang diputus dan ditetapkan oleh hakim Pengadilan Agama

${ }^{2}$ Darmo. Hukum Adat Kumpulan Makalah dan Artikel Terbaik. www. Google. Com, diakses pada tanggal 10 April 2019.
Jambi diberikan kepada si suami selaku pemohon/tergugat hanya terjadi pada tahun 2019 tepatnya dalam perkara putusan Nomor 122/Pdt.G/2019/PA.Jmb.

Putusan No.122/Pdt.G/2019/PA. Jmb, mengemukakan bahwa pemohon dan termohon adalah pasangan suami istri yang menikah sah, dan dari perkawinan Penggugat dan Tergugat telah dikaruniai 2 (dua) orang anak. setelah menjalani kehidupan, beberapa persoalan menimpa keluarga mereka, sehingga antara penggugat dan tergugat sepakat mengajukan perceraian. Pada amar putusannya, hak asuh anak diberikan kepada ayahnya (suami) bukan kepada ibunya. Hal ini tidak seperti pada umumnya hak asuh anak diberikan kepada ibu.

Berdasarkan data awal yang diperoleh peneliti diatas bahwa ada sebagian perkara hak asuh anak yang diberikan kepada ibu dan ada juga hak asuh anak diberikan kepada ayah. Peneliti berharap akan memperoleh data lebih lengkap tentang apa menjadi dasar pertimbangan hakim memberikan hak asuh kepada ayah serta bagaimana akibat hukum yang terjadi setelah penetapan hak asuh anak tersebut.

\section{Perumusan Masalah}

Berdasarkan uraian yang telah penulis paparkan dilatar belakang masalah tersebut, dapat diidentifikasikan perumusan masalah yang akan diteliti, yaitu:

1. Apa yang menjadi pertimbangan hakim menetapkan hak asuh anak diberikan kepada suami selaku pemohon pada Pengadilan Agama Jambi?

2. Bagaimana akibat hukum terhadap hak asuh anak yang diberikan kepada suami selaku pemohon?

\section{METODE}

\section{Tipe penelitian}

Adapun tipe penelitian yang digunakan dalam penulisan ini adalah pendekatan yuridis empiris. Pendekatan yuridis empiris dalam penelitian ini maksudnya adalah bahwa dalam menganalisis permasalahan dilakukan dengan cara memadukan bahanbahan hukum (yang merupakan data sekunder) dengan data primer yang diperoleh di lapangan. ${ }^{3}$

\section{Metode Pendekatan}

Metode pendekatan ini adalah penelitian sociolegal research yaitu mempelajari peraturanperaturan yang berlaku dan melihat prakteknya di lapangan dengan melakukan pendekatan terhadap masalah yang diteliti dan kemudian menganalisisnya. ${ }^{4}$

\footnotetext{
${ }^{3}$ Bahder Johan Nasution, Metode Penelitian Hukum,
} Mandar Maju,Bandung, 2008. halaman. 35.

${ }^{4}$ Ibid, . halaman. 68. 


\section{Spesifikasi Penelitian}

Spesifikasi penelitian berbentuk deskriptif analistis yaitu menggambarkan peraturan perundangundangan yang berlaku dikaitkan dengan teori-teori hukum dan praktek pelaksanaan hokum positif yang menyangkut permasalahan. ${ }^{5}$ Dalam penelitian ini penulis ingin mengkaji tentang pertimbangan hakim dalam menetapkan hak asuh anak kepada suami selaku pemohon pada Pengadilan Agama Jambi.

\section{Sumber data}

\section{Penelitian Lapangan (Field Research)}

Penelitian Lapangan (field research), meliputi penelitian langsung dengan mengadakan wawancara dengan hakim Pengadilan Agama Jambi.

\section{Penelitian Pustaka (Library Research)}

Penelitian Pustaka (library research) berupa bahan-bahan pustaka yang bersumber dari kepustakaan, literatur-literatur yang menyangkut dengan pembahasan skripsi ini, juga peraturan perundang-undangan yang berkaitan dengan masalah yang diteliti.

\section{Teknik pengambilan sampel}

Populasi dalam penelitian ini adalah sebanyak 4 (empat) orang yaitu 3 (tiga) Orang Hakim Pengadilan Agama Jambi

\section{Teknik Pengumpulan Data}

Metode pengumpulan data yang dipergunakan dalam penelitian dan penulisan skripsi ini berupa:

a. Studi dokumen yaitu Putusan Pengadilan Agama Jambi Nomor 122/Pdt.G/2019/PA.Jmb dan Sistem Aplikasi Penelusuran Perkara (SIPP).

b. Wawancara, yaitu dengan melakukan tanya jawab secara langsung kepada informan dan responden dengan dipandu daftar pertanyaan yang telah dipersiapkan terlebih dahulu.

\section{Analisis Data}

Data yang dikumpulkan baik data sekunder ataupun data primer dan diklasifikasikan dalam bentuk yuridis kemudian dianilisis secara kualitatif yaitu dengan menganalisa tanpa perhitungan sistematis atau matematis dalam bentuk pernyataan-pernyataan yang kemudian menghasilkan data yang bersifat deskriptif.

\section{HASIL DAN PEMBAHASAN}

\section{Dasar Pertimbangan Hakim dalam Menetapkan Hak} Asuh Anak Kepada Suami Selaku Pemohon Pada Pengadilan Agama Jambi

Kedudukan Hakim dalam undang-undang secara jelas diatur dalam Pasal 1 ayat (5) Undang-Undang No. 48 Tahun 2009 Tentang Kekuasaan Kehakiman, dalam

${ }^{5}$ Ronny Hanitijo Soemitro, Metode Penelitian Hukum dan Jurimetri, Ghalia Indonesia, Jakarta, 1988. halaman. 35. ketentuan pasal tersebut dinyatakan bahwa: "Hakim adalah hakim pada Mahkamah Agung dan hakim pada badan peradilan yang berada di bawahnya dalam lingkungan peradilan umum, lingkungan peradilan agama, lingkungan peradilan militer, lingkungan peradilan tata usaha negara, dan hakim pada pengadilan khusus yang berada dalam lingkungan peradilan tersebut."

Kewenangan yang diberikan kepada Hakim untuk mengambil suatu kebijaksanaan dalam memutus perkara, diatur dalam Pasal 5 Ayat (1) Undang-Undang Nomor 48 Tahun 2009 tentang Kekuasaan Kehakiman, yang menentukan:

"Hakim dan Hakim konstitusi wajib menggali dan memahami nilai-nilai hukum dan rasa keadilan yang hidup dalam masyarakat". ${ }^{6}$

Berdasarkan aturan hukum tersebut, terdapat norma hukum "mewajibkan Hakim untuk menggali, mengikuti dan memahami nilai-nilai hukum dan rasa keadilan yang hidup dalam masyarakat. Untuk memenuhi norma tersebut, maka Hakim harus mengambil kebijaksanaan hukum". Penentuan atas tuntutan rasa keadilan yang harus diterapkan oleh Hakim dalam memutus suatu perkara.

Nilai- nilai hukum yang hidup dalam masyarakat adalah tidak lain yaitu hukum adat atau hukum yang tidak tertulis. Hakim bertugas sebagai penggalinya dan merumuskannya dalam suatu putusan. Putusan hakim merupakan bagian dari proses penegakkan hukum yang bertujuan untuk mencapai kebenaran hukum atau demi terwujudnya kepastian hukum. Putusan Hakim merupakan produk penegakkan hukum yang didasarkan pada hal-hal yang relevan secara hukum (yuridis) dari hasil proses yang secara sah di persidangan. Pertimbangan hukum para hakim dalam sebuah putusan merupakan determinan dalam melihat kualitas putusan Hakim. $^{7}$

Putusan Hakim merupakan hasil dari proses persidangan di pengadilan. Sementara pengadilan sendiri adalah upaya terakhir bagi para pihak pencari keadilan manakala persolan-persoalan tersebut tidak dapat diselesaikan diluar persidangan. Oleh karena itu putusan Pengadilan tentunya harus dapat memenuhi apa yang dituntut oleh para pencari keadilan. Dengan demikian hakim dalam memutuskan suatu perkara harus tetap

${ }^{6}$ Arief Sidharta. Karakter Penalaran Hukum Dalam Konteks Indonesia, Bandung: Utomo, 2006, halaman. 12

${ }^{7}$ Artidjo Alkostar, Fenomena-Fenomena Paradigmatik Dunia Pengadilan di Indonesia (Telaah Kritis terhadap Putusan Sengketa Konsumen), Jurnal Hukum Ius Quia Lustum, Vol 26 No. 11, Mei 2004, FFH. UII, Yogyakarta, halaman. 1 . Diakses pada situs https://jurnal.hukumonline.com/ pada tanggal 12 Juli 2019. 
bertitik tolak pada ketiga unsur yaitu kepastian hukum, keadilan hukum dan kemanfaatan hukum. ${ }^{8}$

Dengan demikian, Hakim dalam menjalankan tugas dan fungsinya harus mampu menjadi penemu dan pembentuk hukum. Bentham berpendapat bahwa pembentuk hukum dan undang-undang hendaknya melahirkan undang-undang dan putusan yang dapat mencerminkan keadilan bagi semua individu. Dengan berpegang pada prinsip ini, hukum yang dihasilkan hendaknya memberi manfaat dan kebahaagiaan terbesar bagi masyarakat. ${ }^{9}$

Dengan demikain jelaslah bahwa seorang hakim dalam mengambil suatu putusan sangat berperan dalam menemukan hukum melalui pencarian makna normatif dari suatu undang-undang. Pada sisi ini tampak bahwa, hakim tidak semata-mata menggunakan asas legalitas dalam menerapkan hukum, karena banyak kasus atau peristiwa yang belum ada dalam norma legalitas dan karena itu masih membutuhkan pencarian untuk menemukan hukum yang tepat guna menyelesaikan kasus atau peristiwa hukum tertentu. ${ }^{10}$

Korelasi dalam penelitian ini adalah bagaimana Hakim Pengadilan Agama Jambi dalam memberikan putusan atas permohonan hak asuh anak yang ditetapkan pada suami selaku ayah kandungnya, meskipun secara yuridis nornmatif menurut Kompilasi Hukum Islam pasal 105 ditegaskan bahwa anak yang masih mumayyiz, ibu lebih berhak menjalankan hak asuh anak karena ibu lebih mengerti kebutuhan anak dengan kasih sayangnya apalagi anak pada usia tersebut masih ingin berada didekat ibunya dan sangat membutuhkan belai kasih saying seorang ibu. Permasalahan dalam pelaksanaan hak asuh anak pasca perceraian ditemukan pada penyelengaraan pemberian hak atas biaya nafkah setelah hak asuh anak diputus dalam sidang pengadilan.

Ketentuan Dalam Pasal 41 Undang-Undang Nomor 1 Tahun 1974 tentang Perkawinan telah dijelaskan bahwa dalam perceraian yang bertanggung jawab atas biaya nafkah anak, atau dalam hal pemenuhan hak anak adalah orang tua laki-laki (ayah), dan jika ayah tidak dapat memenuhinya maka pengadilan memutuskan bahwa ibu ikut memikulnya.

Kewajiban pemberian nafkah anak ini akan tetap melekat kapada kedua orang tua walaupun penikahannya sudah putus atau cerai. Namun dalam kenyataannya dilapangan, menunjukan bahwa meskipun biaya nafkah anak telah diputus oleh Pengadilan Agama, tetap saja

${ }^{8}$ Fence M. Wanthu, Mewujudkan Kepastiah Hukum, Keadilan dan Kemanfaatan dalam Putusan Hakim Peradilan Perdata, Jurnal Dinamika Hukum, Vol.12. No. 23, September 2012, halaman. 428. Diakses pada situs https://jurnal.hukumonline.com/ pada tanggal 12 Juli 2019.

${ }^{9}$ Jaenal Arifin, Peradilan Agama dalam Bingkai Reformasi Hukum di Indonesia, Kencana Prenada Media Group, Jakarta,2008, halaman. 471.

${ }^{10}$ Ibid. halaman. 474 . ada orang tua laki-laki (ayah) yang tidak mematuhi putusan pengadilan tersebut.

Pemahaman tentang kekuasaan orangtua terhadap anak pasca perceraian orangtua sebagaimana terdapat dalam Pasal 41 Undang-Undang Nomor 1 Tahun 1974, pada dasarnya mengarah pada tanggung jawab orangtua dalam bentuk kewajiban guna untuk memenuhi hak-hak anak. Kewajiban orangtua terhadap anak harus lebih diutamakan daripada hak orangtua terhadap anak sehingga jaminan atas kepentingan anak merupakan sesuatu yang harus diutamakan terlebih dahulu. Orangtua yang bercerai diwajibkan berbuat sesuatu yang terbaik bagi anak, baik ayah ataupun ibu.

Pengertian tersebut di atas memberikan keleluasaan bagi hakim untuk menetapkan hak asuh anak kepada siapapun (baik ayah atau ibunya). Karena sebagaimana diuraikan sebelumnya, bahwa sebenarnya undang-undang perkawinan memiliki paradigma "berikan yang terbaik pada anak". Bahwa terjadinya perceraian terhadap kedua orang tuanya bukan berarti lepas tanggung jawab bagi kedua pasangan tersebut,hal ini di tuntut tanggung jawab penuh atas kepentingan anak yang di dapat dari hasil perkawinan mereka. Perceraian orang tua tidak boleh merugikan kepentingan anak.sebagaimana kita ketahui bahwa anak punya hak atas kelangsungan hidupnya, untuk mendapatkan apa yang dia inginkan, itu menjadi tanggung jawab orang tuanya. karena kasih dan sayang anak hanya bisa di dapat dari kedua orang tuanya.hal ini akan menjadi masalah bagi si anak bila kedua orang tuanya bercerai. Bagi anak akan terpukul mentalnya.akibat pereraian anak sering sekali menjadi korban dari kedua orang tuanya,akibat egois orang tuanya anak menjadi korban.pereraian membuat nasib anak menjadi terombang ambing. Sulit bagi anak untuk mengambil keputusan, karena keduanya sama-sama orang yang mereka sayangi.

Salah satu sampel putusan hakim tentang penetapan hak asuh anak pasca perceraian yang keluar dari ketentuan bunyi pasal peraturan perundangundangan dengan menetapkan hak asuh anak yang belum mumayyiz (belum berusia 12 tahun) ditetapkan pada ayahnya adalah Putusan Pengadilan Agama Jambi No.122/Pdt.G/2019/PA. Jmb, dapat dikemukakan sebagai berikut:

Putusan No.122/Pdt.G/2019/PA. Jmb, mengemukakan bahwa pemohon dan termohon adalah pasangan suami istri yang menikah sah, dan perkawinannya telah dicatat oleh Pegawai Pencatat Nikah Kantor Urusan Agama (KUA), Kecamatan XXX, Kabupaten Muaro Jambi. Bahwa dari perkawinan Pemohon dan Termohon telah dikaruniai 2 (dua) orang anak. setelah menjalani kehidupan berumah tangga beberapa tahun lamanya dan telah di karuniai beberapa orang anak,selama menjalani kehidupan rumah tangga yang di jalani tidak seindah yang di bayangkan selama ini hanya keindahan saja yang tergambar, setelah 
berlangsung lama-kelamaan menjadi masalah, rasa kasih dan sayang dan cinta antara suami istri sudah mulai berkurang sedikit demi sedikit, hal ini di karenakan dengan hadirnya anak dalam perkawinan pada awalnya membuat pasangan ini sangat bahagia, karena merasa kebahagian itu menjadi utuh. Namun kasih sayang seorang suami terhadap anak lebih besar di bandingkan dengan istrinya hal ini tanpa di sadari oleh sang suami, hal ini berkurang dengan sendirinya .karena kehadiran sang buah hati. Tanpa di sadari banyak sekali membawa perubahan dalam kehidupan rumah tangga. Dari berbagai masalah yang di hadapi dalam kehidupan rumah tangga dari pasangan yang bercerai ini sebahagian besar,mengalami hal yang sama.karena kehadiran buah hati dalam kehidupan rumah tangga membuat perhatian seorang suami seara otomatis baik di sadari maupun tidak di sadari tertumpuh pada buah hati mereka. Kehidupan rumaht tangga tidaklah seindah yang di bayangkaan seindah waktu masih berpaaran,karena kewajiban seorang istri bagi suami adalah di samping teman hidup juga ada kewajiban-kewajiban lain yang harus di penuhi oleh seorang istri. Terkadang hal ini tidak di sadari oleh seorang istri,karena dengan dia berkeluarga merasa hidupnya terbeban beberapa persoalan menimpa keluarga mereka, sehingga antara pemohon dan termohon sepakat mengajukan perceraian. Pada amar putusannya, hak asuh anak diberikan kepada ayahnya (suami) bukan kepada ibunya. Hal ini tidak seperti pada umumnya hak asuh anak diberikan kepada ibu.

Bahwa dari dalil permohonan Pemohon yang dihubungkan dengan bukti surat dan keterangan saksisaksi di persidangan, telah terungkap fakta tentang rumah tangga Pemohon dan Termohon sebagai berikut:

1. Bahwa Pemohon dan Termohon adalah suami isteri yang sah yang menikah pada tanggal 13 April 2014 yang dicatat oleh Pegawai Pencatat Nikah Kantor Urusan Agama kota jambi

2. Bahwa antara Pemohon dengan Termohon sejak tahun 2017 mulai tidak harmonis lagi, Termohon sering pergi malam-malam hari tanpa seizin Pemohon bahkan berminggu-minggu dan tidak ada harapan untuk hidup rukun kembali;

3. Bahwa antara Pemohon dengan Termohon sudah berpisah rumah sejak lima bulan yang lalu sampai sekarang;

4. Bahwa terbukti bahwa Termohon sering menelantarkan anak saat Termohon pergi berhari-hari dengan cara menitipkan anak-anak tersebut kepada tetangga ;

5. Bahwa usaha damai dari pihak keluarga sudah dilakukan namun tidak berhasil;

Bahwa berdasarkan fakta-fakta tersebut di atas, Majelis Hakim menilai bahwa rumah tangga Pemohon dan Termohon sudah tidak ada lagi keharmonisan karena sering terjadi perselisihan dan pertengkaran dan tidak ada harapan untuk hidup rukun kembali serta kedua belah pihak sudah tidak sejalan lagi dalam membina rumah tangga, harus dinyatakan bahwa permohonan Pemohon telah memenuhi salah satu alternatif alasan perceraian sebagaimana dimaksud oleh Pasal 19 huruf (f) Peraturan Pemerintah Nomor 9 Tahun 1975 jo. Pasal 116 huruf (f) Kompilasi Hukum Islam di Indonesia (Inpres Nomor 1 Tahun 1991) yang bunyi pasalnya adalah : perceraian dapat terjadi karena alasan:

"Antara suami dan isteri terus-menerus terjadi perselisihan dan pertengkaran dan tidak ada harapan akan hidup rukun lagi dalam rumah tangga".

Bahwa Majelis Hakim berpendapat alasan perceraian sebagaimana ditetapkan Pasal 19 huruf (f) Peraturan Pemerintah Nomor 9 Tahun 1975 Jo. Pasal 116 huruf (f) Kompilasi Hukum Islam tidak ditujukan kepada para pihak, suami atau isteri yang menjalani perkawinan, akan tetapi pada lembaga perkawinannya itu sendiri. Sehingga apabila dalam suatu perkawinan sudah terlihat adanya keretakan dan keretakannya itu sudah sulit untuk diperbaiki dan disatukan kembali, maka cukup alasan untuk membubarkan perkawinan tersebut tanpa mempersoalkan lagi pihak mana yang menjadi penyebab terjadi perselisihan dan atau pertengkaran tersebut;

Bahwa atas dasar pertimbangan tersebut diatas, Majelis Hakim mengambil kesimpulan rumah tangga kedua belah pihak yang berperkara telah pecah sedemikian rupa yang sulit untuk dipersatukan kembali, sehingga tujuan perkawinan sebagaimana yang tercantum dalam Pasal 1 Undang-Undang Nomor 1 Tahun 1974 dan Al-Qur'an Surat Al-Rum ayat (21) tidak tercapai.

Bahwa dari pertimbangan-pertimbangan tersebut di atas, maka sesuai dengan maksud Pasal 39 ayat (2) Undang-Undang Nomor 1 Tahun 1974 jo Pasal 70 ayat (1) Undang-Undang Nomor 7 Tahun 1989, permohonan Pemohon tersebut patut dikabulkan dengan memberi izin kepada Pemohon untuk menjatuhkan talak satu raj'i terhadap Termohon di muka sidang Pengadilan Agama Jambi setelah putusan ini berkekuatan hukum tetap, sesuai dengan maksud Pasal 115, 117, 118 dan Pasal 131 ayat (3) Kompilasi Hukum Islam di Indonesia; Menimbang, bahwa permohonan Pemohon agar hak asuh kedua orang anak diserahkan kepada Pemohon pada dasarnya telah sesuai dengan ketentuan UndangUndang Nomor 1 Tahun 1974 Pasal 45 ayat (1) dan (2) yang berbunyi :

(1) Kedua orangtua wajib memelihara dan mendidik anak-anak mereka sebaik-baiknya.

(2) Kewajiban orangtua yang dimaksud dalam ayat (1) pasal ini berlaku sampai anak itu kawin atau dapat berdiri sendiri, kewajiban mana berlaku terus meskipun perkawinan antara kedua orang tua putus. 
Selanjutnya dalam Pasal 47 ayat (1) UndangUndang Nomor 1 Tahun 1974 yang berbunyi:

"anak yang belum mencapai umur 18 tahun atau belum pernah melangsungkan perkawinan ada di bawah kekuasaan orangtuanya selama mereka tidak dicabut dari kekuasaanya".

Bahwa dalam permohonannya Pemohon mengatakan bahwa Termohon sering menelantarkan kedua anak tersebut karena Termohon sering pergi malam-malam bahkan berminggu-minggu. Pernyataan Pemohon tersebut tidak dibantah oleh Termohon dan pernyataan Pemohon tersebut juga dikuatkan oleh keterangan dua orang saksi, maka dari itu Majelis Hakim dapat menilai bahwa Termohon selaku ibu kandung kedua anak tersebut dapat diduga mempunyai sifat yang buruk/sifat yang tidak baik dalam mengasuh anak.

Bahwa walaupun menurut Pasal 105 huruf (a) Kompilasi Hukum Islam pemeliharaan anak yang belum mumayyiz diserahkan kepada ibunya, namun menurut dalil permohonan Pemohon yang menyatakan bahwa Termohon sejak tahun 2017 sampai sekarang sering pergi berhari-hari tanpa tujuan yang jelas sehingga menelantarkan anak-anak, hal itu tidak dibantah oleh Termohon. Oleh karena itu menurut Majelis Hakim ketentuan pasal 49 ayat (1) huruf a dan b UndangUndang Nomor 1 Tahun 1974 yang berbunyi:

"Salah seorang atau kedua orangtua dapat dicabut kekuasaannya terhadap seorang anak atau lebih untuk waktu yang tertentu atas permintaan orangtua yang lain, keluarga anak dalam garis lurus keatas dan saudara kandung yang telah dewasa atau pejabat yang berwenang, dengan keputusan Pengadilan dalam hal-hal :

a. Ia sangat melalaikan kewajibannya terhadap anaknya.

b. Ia berkelakuan buruk sekali”.

Dapat diberlakukan terhadap Termohon karena Termohon telah terbukti sering pergi malam tanpa seizin Pemohon selaku suaminya sehingga perbuatan Termohon tersebut menelantarkan anak Pemohon dan Termohon, maka dari itu Majelis Hakim perlu mencabut hak asuh kedua anak tersebut dari Termohon selaku ibu kandungnya dan menyerahkan hak asuh dan pemeliharaan kedua orang anak Pemohon dan Termohon tersebut kepada Pemohon selaku ayah kandungnya.

Permohonan Pemohon agar hak asuh kedua orang anak diserahkan kepada Pemohon pada dasarnya telah sesuai dengan ketentuan Undang-Undang Nomor 1 Tahun 1974 Pasal 45 ayat (1) yang berbunyi "Kedua orangtua wajib memelihara dan mendidik anak-anak mereka sebaik-baiknya". Dan ayat (2) berbunyi "Kewajiban orangtua yang dimaksud dalam ayat (1) pasal ini berlaku sampai anak itu kawin atau dapat berdiri sendiri, kewajiban mana berlaku terus meskipun perkawinan antara kedua orangtua putus" dan Pasal 47 ayat (1) Undang-Undang Nomor 1 Tahun 1974 yang berbunyi "(1) anak yang belum mencapai umur 18 tahun atau belum pernah melangsungkan perkawinan ada di bawah kekuasaan orangtuanya selama mereka tidak dicabut dari kekuasaanya".

Majelis Hakim sebagaimana penjelasan sebelumnya diberikan amanah undang-undang untuk memberikan putusan hak asuh anak dengan putusan yang terbaik sesuai makna yang terkandung dalam pasal tentang hak asuh anak yaitu memberikan jaminan yang terbaik bagi kepentingan perkembangan anak itu sendiri. Hakim bisa saja keluar dari bunyi teks yang terdapat dalam undang-undang jika dilihat kemaslahatan anak tersebut lebih maslahat dengan ayahnya. Ini juga dinyatakan oleh Ketua Pengadilan Agama Jambi Mujahidin bahwa:

"Hakim dalam menetapkan hak asuh anak tidak
semata-mata menyandarkan pada bunyi teks dari
pearturan perundang-undangan semata, tapi lebih
dalam lagi hakim harus mampu menggali dan
menemukan filosofi pasal-pasal tentang hak asuh
anak tersebut yaitu adanya jaminan kepentingan dan
kemaslahatan anak yang harus dikedepankan.
Meskipun secara tekstual pasal itu menetapkan hak
asuh anak pada si ibu, akan tetapi berdasarkan
fakta-fakta dipersidangan hakim mendapatkan anak
tersebut lebih terjamin dan lebih baik
perkembangannya bersama sang ayah, maka hakim
dapat menetapkan haka suh anak tersebut pada
ayahnya". ${ }^{11}$

Menurut Pasal 105 huruf (a) Kompilasi Hukum Islam pemeliharaan anak yang belum mumayyiz diserahkan kepada ibunya, namun sekali lagi Hakim dapat menetapkan hak asuh anak pada ayahnya bila ada alasan lain untuk menyimpang dari ketentuan pasal tersebut. Oleh karena itu menurut Majelis Hakim ketentuan pasal 49 ayat (1) huruf a dan b UndangUndang Nomor 1 Tahun 1974 yang berbunyi:

\section{"Salah seorang atau kedua orangtua dapat dicabut kekuasaannya terhadap seorang anak atau lebih untuk waktu yang tertentu atas permintaan orangtua yang lain, keluarga anak dalam garis lurus keatas dan saudara kandung yang telah dewasa atau pejabat yang berwenang, dengan keputusan Pengadilan dalam hal-hal : \\ a. Ia sangat melalaikan kewajibannya terhadap anaknya. \\ b. Ia berkelakuan buruk sekali”.}

${ }^{11}$ Mujahidin, Selaku Ketua/Hakim pada Pengadilan Agama Jambi Kelas IA, Wawancara penulis pada hari senin Tanggal 15 April 2019 Pukul 10.00 Wib. 
Ini pun diperkuat dengan Yurisprudensi Mahkamah Agung RI Nomor : 102/K/Sip/1973 tanggal 24 April 1975 mengenai perwalian anak patokannya ialah bahwa ibu kandung yang diutamakan khususnya bagi anak-anak kecil, kecuali terbukti bahwa ibu tersebut tidak wajar untuk memelihara anak, selaras dengan itu Yurisprudensi Mahkamah Agung RI Nomr 239 K/Sip/1968 menyatakan dalam hal terjadi perceraian, anak yang masih kecil akan membutuhkan kasih sayang dan perawatan ibu, perwaliannya patut diserahkan kepada ibu.

Sedangkan dalam Yurisprudensi Mahkamah Agung Nomor 210K/AG/1996 dan 349K/AG/2006 mengandung kesimpulan hukum bahwa agama merupakan syarat untuk menentukan gugur tidaknya hak seorang ibu atas pemeliharaan dan pengasuhan (hadhanah) terhadap anaknya yang belum mumayyiz sehingga dalam putusan ini memberikan hak perwalian anak kepada ayah.

Menurut H. Djahidin:

"Bahwa karena perkawinan Pemohon dan Termohon sudah diputus karena perceraian dan anak Pemohon dan Termohon masih anak, maka adalah wajar bila anak tersebut tetap seharusnya berada dalam pengasuhan ibunya (Temohon) tetapi dalam perkara ini dijatuhkan kepada bapaknya menimbang perilaku ibunya yang kurang baik dan dipandang menelantarkan anaknya". ${ }^{12}$

\section{H. Efrizal mengemukakan :}

"Bahwa berdasarkan fakta-fakta di persidangan, karena ternyata bahwa anak termohon dan pemohon masih anak-anak yang selama ini berada dan tinggal bersama-sama dengan Pemohon dan berada di bawah asuhan Pemohon, oleh karena tidak terdapat suatu bukti bahwa pemohon mempunyai perilaku yang tidak wajar, dan demi kepentingan terbaik anak mereka, maka Majelis berpendapat agar anak tersebut berada dalam pengasuhan pemohon selaku bapak kandung anak tersebut sampai anak tersebut dewasa". ${ }^{13}$

Pertimbangan yuridis Majelis Hakim dalam menetapkan hak asuh anak juga harus melihat ketentuanketentuan peraturan perundang-undangan secara komprehensif, misalnya dengan melihat dan mempertimbangkan Pasal 49 ayat (1) huruf a dan b Undang-undang nomor 1 tahun 1974 yang berbunyi:

${ }^{12}$ H. Djahidin, Selaku Hakim pada Pengadilan Agama Jambi Kelas IA, Wawancara penulis pada tanggal 11 Juni 2019.

${ }^{13}$ H. Efrizal, Selaku Hakim pada Pengadilan Agama Jambi Kelas IA, Wawancara penulis pada tanggal 11 Juni 2019.
"Salah seorang atau kedua orangtua dapat dicabut kekuasaannya terhadap seorang anak atau lebih untuk waktu yang tertentu atas permintaan orangtua yang lain, keluarga anak dalam garis lurus keatas dan saudara kandung yang telah dewasa atau pejabat yang berwenang, dengan keputusan Pengadilan dalam hal-hal:

a. Ia sangat melalaikan kewajibannya terhadap anaknya.

b. Ia berkelakuan buruk sekali".

Pertimbangan Majelis Hakim dalam menetapkan hak asuh anak dalam perkara hak asuh anak yang ditanganinya dapat dipaparkan bahwa Majelis Hakim mendasarkan putusan tersebut keluar dari ketentuan Pasal 105 Kompilasi Hukum Islam adalah karena demi mewujudkan kemaslahatan dan kepentingan anak itu sendiri, karena jika anak tersebut ditetapkan pada ibu kandungnya, berdasarkan fakta di persidangan ibu kandungnya tidak memenuhi kriteria untuk mengasuh dan memelihara anak tersebut. Selanjutnya hakim juga harus memberikan kepastian hukum atas hak asuh anak tersebut dengan memberikan hak asuh anak kepada suami selaku ayah kandungnya.

Pada bagian sebelumnya telah diuraikan bahwa kekuasaan orangtua terhadap anak pasca perceraian orangtua sebagaimana dalam undang-undang perkawinan tersebut di atas, pada dasarnya mengarah pada tanggung jawab orangtua dalam bentuk kewajiban guna untuk memenuhi hak-hak anak. Pengutamaan kewajiban orangtua daripada hak orangtua terhadap anak, di dalam konteks kekuasaan orangtua terhadap anak, pada akhirnya melahirkan suatu rumusan bahwa jaminan atas kepentingan anak merupakan hal utama yang harus direalisasikan. Orangtua yang bercerai diwajibkan berbuat sesuatu yang terbaik bagi anak, baik ayah ataupun ibu.

Hal ini memberikan keleluasaan bagi hakim untuk menetapkan hak asuh anak kepada siapapun (baik ayah atau ibunya). Karena sebagaimana diuraikan sebelumnya, bahwa sebenarnya undang-undang perkawinan memiliki paradigma "berikan yang terbaik pada anak". Bahwa adanya perceraian orangtua tetap menuntut tanggung jawab penuh atas kepentingan anak hasil perkawinan mereka. Anak tidak boleh kehilangan haknya sedikitpun meskipun kedua orangtuanya telah bercerai.

Berdasarkan uraian di atas, pada umumnya Majelis Hakim dalam mempertimbangkan hak asuh anak yang ditetapkan pada ayahnya dalam perkara putusan Pengadilan Agama Jambi No. 122/Pdt.G/2019/PA.Jmb adalah sebagai berikut:

1. Kemaslahatan anak, sebelum memutuskan hak asuh anak kepada ayah, terlebih dahulu majelis hakim mempertimbangkan kemaslahatan bagi anak. Ini didasarkan pada fakta-fakta persidangan yang diperoleh hakim dari alat bukti saksi misalnya. Saksi 
tersebut menerangkan kondisi objektif tentang keadaaan anak selama ini sehingga dapat disimpulkan bahwa anak tersebut lebih maslahat tinggal bersama ayahnya.

2. Persetujuan bersama, dalam praktik persidangan sering terjadi kesepakatan antara orangtua (suamiisteri), dimana isteri menyerahkan hak asuh anak kepada suami (ayahnya) dengan pertimbangan kesejahteraan anak lebih terjamin bila tinggal bersama ayahnya karena faktor ekonomi yang bisa menopang terjaminnya biaya pendidikan, kesehatan dan lain sebagainya.

3. Ibu kandung mempunyai perilaku yang buruk. Pertimbangan Majelis Hakim menetapkan hak asuh anak yang masih di bawah umur adalah karena pertimbangan kehawatiran anak meniru perilaku buruk ibunya yang mana dipersidangan telah terbukti fakta bahwa ibu kandung telah melanggar kesusilaan yang dikhawatirkan perilaku dan perbuatan tersebut ditiru oleh anak.

4. Faktor Ekonomi, Kemampuan ekonomi menjadi dasar pertimbangan Majelis Hakim dalam menetpakan hak asuh anak pada ayahnya. Biasanya apabila hak asuh anak diberikan pada ibunya terkadang ayah kurang memberikan dan tidak melaksanakan atau melalaikan kewajibanya berupa nafkah untuk anaknya.

5. Kedekatan anak pada ayahnya, majelis Hakim juga mempertimbangkan kedekatan dan kenyamanan anak dalam menetapkan kepada siapa anak tersebut ditetapkan hak asuhnya. Meskipun masih di bawah umur akan tetapi anak tersebut sudah lama tinggal bersama ayahnya dan mempunyai kedekatan psikologis yang lebih daripada dengan ibunya, maka hak asuh anak tersebut ditetapkan pada ayahnya kalau diberikan kepada ibunya akan berdampak buruk pada kenyamanan anak tersebut.

6. Adanya kemampuan dan kemauan untuk memelihara dan mendidik anak. Bahwa ayah tersebut mempunyai kemampuan dan kemauan untuk mendidik dan memelihara anak dan tidak terikat dengan suatu pekerjaan yang bisa mengakibatkan tugas mengasuh anak jadi terlantar.

Dalam konteks pemenuhan dan adanya jaminan kesejahteraan anak dalam setiap putusan hakim mengenai hak asuh anak, ada beberapa syarat yang perlu dipertimbangkan hakim sebelum menjatuhkan putusan. Adapun syarat-syarat tersebut antara lain: ${ }^{14}$

1) Yang melakukan pemeliharaan hak asuh anak adalah orang yang sehat jasmani dan rohaninya, karena dalam upaya pemeliharaan anak merupakan pekerjaan yang penuh dengan tanggung jawab.

2) Mempunyai kemampuan dan kemauan untuk memelihara dan mendidik anak dan tidak terikat suatu pekerjaan yang mengancam kelancaran kegiatan memelihara dan mengasuh anak.

3) Yang memelihara anak adalah orang yang amanah sehingga dapat menjamin kemaslahatan dan kesejahteraan anak.

4) Jika anak itu ditetapkan kepada ibu kandungnya, diupayakan tidak menikah dulu dengan laki-laki lain.

5) Seorang yang melakukan hadhanah atau pemeliharaan anak hendaklah orang yang beragama Islam, jika anak tersebut adalah beragama Islam.

Selain itu, untuk mengambil keputusan yang tepat tentang hak asuh anak, seorang hakim pun membutuhkan pendekatan. Misalnya melalui aspek psikologi dan sosial. Pendekatan psikologi tujuannya agar hakim memahami kondisi anak bukan sekedar dari segi umur, tetapi kualitas kematangan psikologi anak. Bila anak dirasa sudah matang secara psikologis, maka anak dikatakan mumayyiz. Perlu diketahui, pertimbangan psikologis juga berlaku bagi orang tua yang mendapat hak mengasuh anak. Hal ini penting lantaran tidak sedikit kasus orangtua bermasalah, baik dengan diri sendiri atau dengan lingkungan sekitar dan tidak terkecuali anak. Ikatan emosional orangtua dengan anak juga menjadi pertimbangan. Bila ternyata kondisi orangtua tidak baik, jelas tidak mampu merawat anak. Salah-salah malah bisa memperburuk kondisi anak yang sudah cukup terguncang pasca perceraian orangtua.

Selain pertimbangan di atas, untuk menjaga kemaslahatan dan kepentingan sebagaimana yang diamanahkan dalam peraturan perundang-undangan, maka Majelis Hakim seharusnya perlu memberikan dan menguraikan batasan-batasan hak asuh anak yang diberikan pada ayahnya. Batasan-batasan tersebut antara lain adalah adanya pertimbangan bahwa ibu kandungnya masih diperbolehkan dan diizinkan dapat bertemu dan bergaul dengan anak tersebut dengan menguraikan waktunya, atau dengan kata lain sang ayah tidak boleh membatas-batasi atau melarang waktu anak bertemu dengan ibunya selagi tidak menggangu kepentingan anaknya ini penting untuk dipertimbangkan agar putusan hak asuh anak pada dasarnya adalah untuk kepentingan dan kemaslahatan anak itu sendiri bukan kepentingan orangtua semata.

\section{Akibat Hukum Terhadap Hak Asuh Anak Yang Diberikan Kepada Suami Selaku Pemohon}

Akibat hukum, sebagaimana telah diuraikan pada sub bab landasan teoritis, adalah akibat yang ditimbulkan oleh peristiwa hukum. Karena suatu peristiwa hukum disebabkan oleh perbuatan hukum, sedangkan suatu perbuatan hukum juga dapat melahirkan suatu hubungan hukum, maka akibat hukum juga dapat dimaknai sebagai suatu akibat yang ditimbulkan oleh adanya suatu perbuatan hukum dan/atau hubungan hukum. 
Lebih jelas lagi menurut Syarifin yang menyatakan bahwa :

\begin{abstract}
"Akibat hukum adalah segala akibat yang terjadi dari segala perbuatan hukum yang dilakukan oleh subyek hukum terhadap obyek hukum atau akibatakibat lain yang disebabkan karena kejadiankejadian tertentu oleh hukum yang bersangkutan telah ditentukan atau dianggap sebagai akibat hukum". ${ }^{15}$
\end{abstract}

Berdasarkan uraian tersebut, untuk dapat mengetahui telah muncul atau tidakya suatu akibat hukum, maka yang perlu diperhatikan adalah hal-hal sebagai berikut:

a. Adanya perbuatan yang dilakukan oleh subyek hukum terhadap obyek hukum atau terdapat akibat tertentu dari suatu perbuatan, yang mana akibat itu telah diatur oleh hukum.

b. Adanya perbuatan yang seketika dilakukan bersinggungan dengan pengembanan hak dan kewajiban yang telah diatur dalam hukum (undangundang)

Dengan demikian, dalam pembahasan sub bab ini, yang akan menjadi fokus pembahasannya adalah akibat hukum dari penetapan hak asuh anak yang ditetapkan kepada ayah oleh putusan Pengadilan Agama akibat terjadinya perceraian antara suami isteri (orangtua) sang anak. Akibat hukum ini, sebagaimana didasarkan pada teori di atas, meliputi hak-hak anak terhadap orang tuanya yang menjadi kewajiban orangtuanya dan sebaliknya yaitu kewajiban orangtua terhadap anak yang menjadi hak anak yang didasarkan pada peraturan perundang-undangan termasuk putusan hakim itu sendiri.

\section{Hak-Hak Anak Pasca Terjadinya Perceraian Orangtuanya}

Menurut Pasal 14 Undang-undang Nomor 35 Tahun 2014 tentang Perubahan Atas Undang-undang Nomor 23 Tahun 2002 tentang Perlindungan anak yang berbunyi "Setiap anak berhak untuk diasuh oleh orangtuanya sendiri, kecuali jika ada alasan atau aturan hukum yang sah menunjukan bahwa pemisahan itu adalah demi kepentingan terbaik bagi anak dan merupakan pertimbangan terakhir" 16

Selanjutnya pada Dalam Pasal 41 Undang-Undang Nomor 1 Tahun 1974 tentang Perkawinan telah dijelaskan bahwa dalam perceraian yang bertanggung jawab atas biaya nafkah anak, atau dalam hal pemenuhan hak anak adalah orangtua laki-laki (ayah), dan jika ayah

\footnotetext{
${ }^{15}$ Pipin Syarifin, Pengantar Ilmu Hukum, CV. Pustaka Setia, Bandung, 2009. halaman. 12.

${ }^{16}$ Siti Nurhidayati, Op. Cit., Diakses Tanggal 02 Agustus 2019 Pukul 22.00 Wib.
}

tidak dapat memenuhinya maka pengadilan memutuskan bahwa ibu ikut memikulnya.

Lebih rinci lagi ketentuan Undang-Undang Nomor 1 Tahun 1974 Pasal 45 ayat (1) yang berbunyi "Kedua orangtua wajib memelihara dan mendidik anak-anak mereka sebaik-baiknya". Dan ayat (2) berbunyi "Kewajiban orang tua yang dimaksud dalam ayat (1) pasal ini berlaku sampai anak itu kawin atau dapat berdiri sendiri, kewajiban mana berlaku terus meskipun perkawinan antara kedua orangtua putus"

Kewajiban pemberian nafkah anak ini akan tetap melekat kepada kedua orangtua walaupun penikahannya sudah putus atau cerai. Namun dalam kenyataannya dilapangan, menunjukan bahwa meskipun biaya nafkah anak telah diputus oleh Pengadilan Agama, tetap saja ada orangtua laki-laki (ayah) yang tidak mematuhi putusan pengadilan tersebut.

Kekuasaan orangtua terhadap anak pasca perceraian orangtua sebagaimana dalam undang-undang perkawinan tersebut di atas, pada dasarnya mengarah pada tanggung jawab orangtua dalam bentuk kewajiban guna untuk memenuhi hak-hak anak. Pengutamaan kewajiban orangtua daripada hak orangtua terhadap anak, didalam konteks kekuasaan orangtua terhadap anak, pada akhirnya melahirkan suatu rumusan bahwa jaminan atas kepentingan anak merupakan keutamaan yang harus direalisasikan. Orangtua yang bercerai diwajibkan berbuat sesuatu yang terbaik bagi anak, baik ayah ataupun ibu.

Dengan demikian, hak-hak anak tetap harus dipenuhi oleh kedua orangtuanya meskipun telah terjadi perceraian antara ayah dan ibu anak tersebut, tanpa melihat kepada siapapun hak asuh anak itu ditetapkan, karena yang menjadi dasar dari ketentuan peraturan perundang-undangan adalah kepentingan dan kesejahteraan anak yang didahulukan dari kepentingan kedua orangtuanya tersebut. Hak-Hak tersebut meliputi:

a. Hak memperoleh nafkah dari orangtua yang meliputi biaya sandang, pangan, pendidikan, kesehatan dan lain-lain yang berkaitan dan menunjang kepentingan dan kesejahteraan hidup anak. Ini didasarkan pada ketentuan Undang-Undang Nomor 1 Tahun 1974 Pasal 45 ayat (1) yang berbunyi "Kedua orangtua wajib memelihara dan mendidik anak-anak mereka sebaik-baiknya". Dan ayat (2) yang berbunyi "Kewajiban orangtua yang dimaksud dalam ayat (1) pasal ini berlaku sampai anak itu kawin atau dapat berdiri sendiri, kewajiban mana berlaku terus meskipun perkawinan antara kedua orangtua putus". Dengan demikain Hakim juga harus mempertimbangkan secara jelas tentang hak-hak anak disatu sisi dan kewajiban orangtua disisi lain sebagai akibat hukum terjadinya perceraian.

b. Hak mendapatkan kasih sayang dari kedua orangtuanya yang telah bercerai. Dengan demikian maka menjadi sesuatu yang mutlak dalam putusan hakim harus memuat pertimbangan-pertimbangan 
hukum yang mengarah pada kepentingan kasih sayang anak tersebut. Misalnya, meskipun anak tersebut ditetapkan hak asuhnya kepada ayahnya, maka hakim harus tetap mempertimbangkan hak anak untuk memperoleh kasih sayang dari ibunya seperti mengatur dan menetapkan jadwal bertemu anak tersebut dengan ibunya dan memerintahkan kepada ayah selaku penerima hak asuh anak agar tidak menghalang-halangi anak untuk bertemu dengan ibu kandungnya. Ini akibat hukum dari perceraian yang terjadi diantara suami isteri tersebut.

\section{Kewajiban orangtua pasca perceraian terhadap anaknya}

Setelah dibahas tentang hak-hak anak, maka pada bagian ini akan dibahas sebaliknya yaitu kewajiban orangtua terhadap anak atau dengan kalimat lain adalah bentuk tanggung jawab orangtua terhadap anak. Bentuk tanggung jawab orangtua kepada anaknya tidak terhenti pada suatu akibat perceraian. Orangtua masih berkewajiban untuk melaksanakan tanggung jawabnya seperti menanggung biaya hidup bagi anaknya, memberikan tempat tinggal yang layak, serta memberikan kiswah bagi anak-anaknya sehingga anak dapat berkembang dan tumbuh sebagaimana mestinya, tidak terhalangi oleh akibat suatu perceraian yang terjadi terhadap kedua orang tua mereka. Sebagaimana diatur dalam Pasal 41 Undang-Undang Nomor 1 Tahun 1974 bahwa akibat suatu perceraian kedua orangtua tetap berkewajiban memelihara dan mendidik anak-anaknya semata-mata berdasarkan kepentingan anak.

Kemudian pembahasan mengenai tanggung jawab orangtua setelah perceraian juga disebut dalam pasal 149 huruf $\mathrm{d}$ Kompilasi Hukum Islam disebut bahwa: "Bilamana perkawinan putus karena talak, maka bekas suami wajib memberikan biaya hadhanah untuk anakanaknya yang belum mencapai umur 21 tahun". Pengertian hadhanah menurut Pasal 1 Huruf g Kompilasi Hukum Islam adalah: "pemeliharaan anak, yaitu kegiatan mengasuh, memelihara dan mendidik anak hingga dewasa atau mampu berdiri sendiri".

Hak lain yang melekat pada anak, termasuk kewajiban orangtua bagi anak juga termuat dalam Undang-Undang Nomor 35 Tahun 2014 tentang Perubahan Atas Undang-Undang Nomor 23 Tahun 2002 Tentang Perlindungan Anak. Pasal 4 menyebutkan bahwa: "Setiap anak berhak untuk dapat hidup, tumbuh, berkembang dan berpartisipasi secara wajar sesuai dengan harkat dan martabat kemanusiaan, serta mendapat perlindungan dari kekerasan dan diskriminasi".

Mengenai tanggung jawab orangtua juga disebutkan dalam Pasal 9 Undang-Undang No. 4 Tahun 1979 yang menyatakan bahwa "orangtua adalah yang pertama-tama bertanggung jawab atas terwujudnya kesejahteraan anak baik secara rohani, jasmani maupun sosial".
Dalam Pasal 3 ayat (1) Peraturan Pemerintah Nomor 44 Tahun 2017 tentang Pelaksanaan Pengasuhan Anak menyatakan "Setiap anak berhak untuk diasuh oleh orangtuanya sendiri."

Berdasarkan hal tersebut ayah wajib memberikan biaya nafkah kepada anaknya setiap bulan, dan demi kepentingan si anak maka kedua orangtua wajib memberikan asuhan sebaik-baiknya.

Akibat hukum yang berkaitan dengan kewajiban orangtua terhadap anak secara detail dituangkan dalam Kompilasi Hukum Islam. Dalam Kompilasi Hukum Islam setidaknya ada dua pasal yang menentukan pengasuhan anak yaitu Pasal 77, 105 dan 156. Sebagaimana terdapat pada pasal 77, 105 dan 156 Kompilasi Hukum Islam yang bunyi lengkapnya adalah sebagai berikut:

Pasal 77 Kompilasi Hukum Islam menyebutkan:

1. Suami Istri memikul kewajiban yang luhur untuk menegakkan rumah tangga yang sakinah, mawaddah dan rahmah yang menjadi sendi dasar dari susunan masyarakat.

2. Suami Istri wajib saling mencintai, hormat menghormati, setia dan memberikan bantuan lahir batin yang satu kepada yang lain.

3. Suami Istri memikul kewajiban untuk mengasuh dan memelihara anak-anak mereka, baik mengenai pertumbuhan jasmani, rohani maupun kecerdasannya dan pendidikan agamanya.

4. Suami Istri wajib memelihara kehormatannya.

5. Jika suami istri melalaikan kewajibannya, masingmasing dapat mengajukan gugatan kepada Pengadilan Negeri.

Pasal 105 Kompilasi Hukum Islam menyatakan bahwa :

1. Pemeliharaan anak yang belum mumayyiz atau belum berumur 12 (dua belas) tahun adalah hak ibunya;

2. Pemeliharaan anak yang sudah mumayyiz diserahkan kepada anak untuk memilih diantara ayah atau ibunya sebagai pemegang hak pemeliharaannya;

3 . Biaya pemeliharaan ditanggung oleh ayahnya; bahwa:

Pasal 156 Kompilasi Hukum Islam menyatakan

Akibat putusnya perkawinan karena perceraian ialah:

1. Anak yang belum mumayyiz berhak mendapatkan hadhanah dari ibunya, kecuali bila ibunya telah meninggal dunia, maka kedudukannya digantikan oleh:

a. Wanita-wanita dalam garis lurus dari ibu;

b. Ayah;

c. Wanita-wanita dalam garis lurus ke atas dari ayah;

d. Saudara perempuan dari anak yang bersangkutan;

e. Wanita-wanita kerabat sedarah menurut garis samping dari ibu; 
f. Wanita-wanita kerabat sedarah menurut garis samping dari ayah.

2. Anak yang sudah mumayyiz berhak memilih untuk mendapatkan hadhanah dari ayah atau ibunya;

3. Apabila pemegang hadhanah ternyata tidak dapat menjamin keselamatan jasmani dan rohani anak, meskipun biaya nafkah dan hadhanah telah dicukupi, maka atas permintaan kerabat yang bersangkutan Pengadilan Agama dapat memindahkan hak hadhanah kepada kerabat lain yang mempunyai hak hadhanah pula;

4. Semua biaya hadhanah dan nafkah anak menjadi tanggungan ayah menurut kemampuannya, sekurangkurangnya sampai anak tersebut dewasa dan dapat mengurus diri sendiri (21 tahun);

5. Bilamana terjadi perselisihan mengenai hadhanah dan nafkah anak, Pengadilan Agama memberikan putusannya berdasarkan Huruf (a), (b), (c), dan (d);

6. Pengadilan dapat pula dengan mengingat kemampuan ayahnya menetapkan jumlah biaya untuk pemeliharaan dan pendidikan anak yang tidak turut padanya.

Berdasarkan ketentuan Kompilasi Hukum Islam tersebut maka kewajiban dalam memberikan nafkah adalah dibebankan kepada Ayahnya, terlebih jika ayah ditetapkan sebagai penerima hak asuh anak berdasarkan putusan pengadilan.

Orangtua mempunyai kewajiban yang sama dalam memberikan kasih sayang kepada anaknya setelah terjadinya perceraian, bahkan kewajiban ini melebih dari kewajiban memberikan nafkah lahiriah, ini jelas terlihat dalan ketentuan Kompilasi Hukum Islam Pasal 156 angka 3 "Apabila pemegang hadhanah ternyata tidak dapat menjamin keselamatan jasmani dan rohani anak, meskipun biaya nafkah dan hadhanah telah dicukupi, maka atas permintaan kerabat yang bersangkutan Pengadilan Agama dapat memindahkan hak hadhanah kepada kerabat lain yang mempunyai hak hadhanah pula". Secara eksplisit ketentuan ini menekankan pentingnya kasih sayang orangtua kepada anak bahkan hak asuh nya dapat dicabut oleh pengadilan meskipun nafkah yang diberikan memenuhinya dan cukup akan tetapi tidak dapat menjamin keselamatan anak tersebut.

\section{SIMPULAN}

Berdasarkan uraian yang telah dijelaskan pada bab-bab sebelumnya, maka penulis berkesimpulan sebagai berikut:

1. Bahwa dalam perkara Nomor 122/Pdt.G/2019/PA. Jmb Pertimbangan Majelis Hakim dalam menetapkan hak asuh anak yang belum mencapai usia 12 tahun kepada ayah kandungnya secara psikologis karena demi mewujudkan kemasalahatan dan kepentingan anak itu sendiri, karena jika anak tersebut ditetapkan pada ibu kandungnya, yang didasarkan pada fakta di persidangan ibu kandungnya tidak memiliki kecakapan dan kemampuan untuk memenuhi kepentingan anak secara normal. Pertimbangan Majelis Hakim telah sejalan dengan apa yang dimaksud Pasal 41 huruf a Undang-Undang Nomor 1 Tahun 1974 jo Pasal 156 huruf a Kompilasi Hukum Islam serta maksud Pasal 14 Undang-Undang Nomor 23 Tahun 2002 tentang perlindungan anak ("setiap anak berhak untuk diasuh oleh orang tuanya sendiri, kecuali jika ada alasan atau aturan hukum yang sah yang menunjukan bahwa pemisahan itu adalah demi kepentingan terbaik bagi anak dan merupakan pertimbangan terakhir").

2. Akibat hukum dari hak asuh anak yang diberikan pada ayahnya setelah terjadinya perceraian adalah bahwa orangtua masih berkewajiban untuk melaksanakan tanggung jawabnya seperti menanggung biaya hidup bagi anaknya, memberikan tempat tinggal yang layak, serta memberikan kiswah bagi anak-anaknya sehingga anak dapat berkembang dan tumbuh sebagaimana mestinya, tidak terhalangi oleh akibat suatu perceraian yang terjadi terhadap kedua orangtua mereka. Sebagaimana diatur dalam Pasal 41 Undang-Undang Nomor 1 Tahun 1974 bahwa akibat suatu perceraian kedua orangtua tetap berkewajiban memelihara dan mendidik anakanaknya semata-mata berdasarkan kepentingan anak. Kemudian pembahasan mengenai tanggung jawab orangtua setelah perceraian juga disebut dalam pasal 149 huruf d Kompilasi Hukum Islam disebut bahwa: "Bilamana perkawinan putus karena talak, maka bekas suami wajib memberikan biaya hadhanah untuk anak-anaknya yang belum mencapai umur 21 tahun".

\section{Saran}

Dalam kesempatan ini penulis mencoba memberikan saran yang kemungkinan ada gunanya bagi para pembaca. Adapun saran yang dapat penulis sampaikan adalah sebagai berikut:

1. Majelis Hakim seharusnya dalam pertimbangan putusan terhadap penetapan hak asuh anak harus diuraikan secara jelas dengan melihat kepentingan dan kesejahteraan anak secara luas yang meliputi terjaminnya pendidikan, kesehatan, sandang, pangan dan terjamninnya keselamatan jasmani dan rohaninya dan yang lebih penting adalah agama sang anak.

2. Hendaknya bagi orangtua, sekalipun terjadi perceraian, kedua orangtua harus tetap bertanggung jawab penuh terhadap anak-anaknya tanpa terhalang oleh waktu dan keadaan dan karena kewajiban orangtua terhadap anak pada dasarnya tidak putus karena perceraian dan sebaliknya anak tetap memperoleh hak-haknya dari kedua orangtuanya yang telah bercerai. 


\section{DAFTAR PUSTAKA}

\section{Buku}

Abdul Rahman Ghazali, Fiqih Munakahat, Kencana Prenada Group, Jakarta, 2010.

Arief Sidharta. Karakter Penalaran Hukum Dalam Konterks Indonesia, Bandung: Utomo, 2006.

Bahder Johan Nasution. Metode Penelitian Hukum. Mandar Maju, Bandung, 2008.

Jaenal Arifin, Peradilan Agama dalam Bingkai Reformasi Hukum di Indonesia, Kencana Prenada Media Group, Jakarta,2008, Hal. 471.

Ronny Hanitijo Soemitro, Metode Penelitian Hukum dan Jurimetri, Ghalia Indonesia, Jakarta, 1988.

\section{Jurnal}

Artidjo Alkostar, Fenomena-Fenomena Paradigmatik Dunia Pengadilan di Indonesia (Telaah Kritis terhadap Putusan Senketa Konsumen), Jurnal Hukum Ius Quia Lustum, Vol 26 No. 11, Mei 2004.

Fence M. Wanthu, Mewujudkan Kepastiah Hukum, Keadilan dan Kemanfaatan dalam Putusan Hakim Peradilan Perdata, Jurnal Dinamika Hukum, Vol.12. No. 23, September 2012.

\section{Website}

Darmo. Hukum Adat Kumpulan makalah dan Artikel Terbaik. www.Google.com.

www.pa-jambi.go.id.

\section{Peraturan Perundang-undangan}

Republik Indonesia. Undang-Undang Nomor 1 Tahun 1974 tentang Perkawinan (Lembaran Negara Republik Indonesia Tahun 1974 Nomor 1, Tambahan Lembaran Negara Republik Indonesia Nomor 3019).

Republik Indonesia. Undang-Undang Nomor 35 Tahun 2014 Tentang Perubahan Atas Undang-Undang Nomor 23 Tahun 2002 Tentang Perlindungan Anak (Lembaran Negara Republik Indonesia Tahun 2014 Nomor 297, Tambahan Lembaran Negara Republik Indonesia Nomor 5606).

\section{Wawancara}

Mujahidin, Selaku Ketua/Hakim pada Pengadilan Agama Jambi Kelas IA, Wawancara penulis pada hari senin Tanggal 15 April 2019 Pukul 10.00 Wib.

H. Djahidin, Selaku Hakim pada Pengadilan Agama Jambi Kelas IA, Wawancara penulis pada tanggal 11 Juni 2019.

H. Efrizal, Selaku Hakim pada Pengadilan Agama Jambi Kelas IA, Wawancara penulis pada tanggal 11 Juni 2019.

Satria Effendi M. Zein, Op. Cit., Hlm. 172.

Pipin Syarifin, Pengantar Ilmu Hukum, CV. Pustaka Setia, Bandung, 2009. halaman. 12.
Siti Nurhidayati, Op. Cit., Diakses Tanggal 02 Agustus 2019 Pukul 22.00 Wib. 